Egypt. J. of Nutrition and Health Vol. 15 No. 2 July (2020)

\title{
Dietary Patterns, Prevalence and Predictors of Obesity among Medical Students in Cairo University
}

\author{
Eman H.ElHabashi, Shereen Esmat, Fayrouz El-Aguizy and Eman Fouad Ataya \\ Public Health and community Medicine faculty of medicine, Cairo Univ
}

\begin{abstract}
Background: Non Communicable Diseases is intensely linked with overweight and obesity. The shifting disease pattern has been attributed to nutrition transition and poor exercise. This study was conducted to identify the dietary consumption patterns, assessing obesity among medical students and its predictors. Methods: A cross-sectional study was conducted with 350 fourth year medical students in a university setting. Dietary patterns were assessed using self administered questionnaire based on United States Department of Health and Human Services and United States Department of Agriculture dietary guidelines for Americans 2015-2020. Body mass index (BMI) was calculated by the researchers. Results: The prevalence of overweight and obesity was $32 \%$ and $9 \%$ respectively, among the participants. Unfortunately, $29.1 \%$ of the studied group were found to have low level of exercise. Intakes of fruits, and vegetables were low, while intakes of sweets and carbonated drinks were high. There was a significant higher percent of obesity among students who practice low level of physical activity $(P<0.05)$. Also the study revealed by logistic regression analysis that male students were more than 2 times more likely to be obese than female students (Odd's Ratio $=2.16$ ).

ConclusionThe prevalence of obesity was $9 \%$ among the studied group. Students were found to practice unhealthy dietary and lifestyle habits which had significant effects on their Body Mass Index levels.

Keywords: Dietary Patterns; Medical students; Body Mass Index (BMI); Obesity; Physical Activity; Food Frequency.
\end{abstract}

\section{Introduction}

Importance of studying relationships between dietary habits and health has imposed its-self on the research fields owing to the vital role that nutrition and diet play a role in prevention and treatment of acute and chronic diseases. In addition to that, the growing burden caused by unhealthy lifestyle related-diseases on health sectors. [WHO 2009 - Vibhute et al., 2018]

Poor eating habits contribute to the occurrence of a group illnesses known as metabolic syndrome and to increase the risk of developing a number of non-communicable diseases which in return negatively affects one's wellbeing and reduce the ability to lead a healthy life [Alberti et al.,

2005- Grundy et al., 2005- Agyei and de-Graft, 2010]. A significant impact of rapid changes in diets and lifestyles on health and nutrition status of populations, particularly in developing countries is now very much observed [WHO 2003]. Generally speaking college students are more likely to demonstrate many unhealthy lifestyle practices especially with those related to dieting [Rao et al., 2012- Likus et al., 2013]. Some studies in university students have shown the presence of unhealthy lifestyles and 


\section{Eman H.ElHabashi, et al}

unbefitting health behaviors [Azadbakht and Esmaillzadeh, 2012- Senekal et al., 2016- Turhan et al., 2016].

On the other hand, medical students expected to have better information about the proper dietary habits and healthy lifestyle when compared with non-medical students. Out of those medical students (future physicians) the ones who embrace a healthy lifestyle including diet and physical activities, will definitely have a positive influence on their patients and hence the significance of them adopting a healthy lifestyle. Yet, studies showed that medical and paramedical students sometimes are at risk of irregular dietary habits and lack of exercise [Gupta et al., 2009-Sajwani et al., 2009].

However, the growing problem of obesity has been detected in many lower-income countries in the last decades. Egyptian adults, unfortunately, were recognized as one of the highest levels of obesity in the Eastern Mediterranean Region, according to World Health Organization (WHO). [WHO EMRO, 2019] Available detailed information on the eating habits of health sector professionals is very limited, especially in Egypt.

Aim of the study is to evaluate dietary consumption patterns and to assess prevalence of obesity and it's predictors among fourth year medical students of Cairo University.

\section{Materials and Methods}

\section{Study design:}

An analytical cross-sectional study was conducted. A convenient sample of medical students was selected, where participants were recruited voluntary after explaining the study procedures and goal. Questionnaires were anonymous to ensure confidentiality of the study's data.

\section{Study setting \& population}

This study was implemented at Public health and community medicine department, Faculty of Medicine, Cairo University, Egypt among fourth year medical students ( $N=350)$ during the academic year 2018-2019. After finishing a detailed nutrition science module at the Public Health specialty round, the subjects were allowed to decide to participate or not, as the investigators explain the study.

\section{Sample size:}

The total number of fourth year medical students attending nutrition science module was 1200 students. The sample size was calculated to recruit 350 participants. The calculation of the sample size goes according to "Sampsize.sourceforge.net" software program. Assuming precision 5\%, confidence level 95\%, prevalence of obesity 15\% [Gopalakrishnan et al., 2012].

\section{Data collection tools:}

A modified self-administered questionnaire - based on the questionnaire developed by United States (U.S.) Department of Health and Human Services and U.S. Department of Agriculture Services and U.S. Department of Agriculture [Dietary Guidelines for Americans, 2015] -was used in collecting the data and it included the following sections:

a) Section for the socio- demographic characteristics (for an example; age, sex, residence, level of parents' education and professions', height, weight)

b) Section for the practicing physical activities (pattern of daily exercise and sedentary activities practicing)

c) Section for dietary consumption patterns (Frequency consumption for selected food items) 


\section{Egypt. J. of Nutrition and Health Vol. 15 No. 2 July (2020)}

Food frequency questionnaire (FFQ) was used to assess nutritional intake of some selected food items during the last 30 days. Responses were recorded by the students themselves according to their consumption patterns. Each food item consumption frequency options were either; its daily consumed or weekly consumed or never consumed in the past month. Body mass index (BMI) was calculated after accurate assessment of weight and height of students by the researchers at nutritional laboratory practical session. When measuring the height of each participant, he/she was asked to stand up straight on the stadiometer, look straight ahead, rest the $L$ board on top of the head and record the measurement to the nearest $1 / 2$ centimeter. While when measuring the weight of each participant, he/she was asked to remove heavy outer clothing and his/her shoes, after making sure that the mechanical bathroom scale reads zero, he/she was asked to stand on the scale without moving and record the measurement to the nearest $1 / 2$ kilo.

\section{Pilot test:}

The questionnaire was tested on 10 students to check the validity and clarity of the questions and to estimate the time needed to complete the questionnaire. The questionnaires of pilot study were not included in the analysis.

\section{Data collection:}

The questionnaires were distributed by the researchers after the students have attended the nutritional laboratory session where their weight and height were recorded and their BMl were calculated. The students were recruited to fulfill the modified self- administrated questionnaire after explaining the aim of work.

\section{Data management and analysis:}

All collected questionnaires were revised for completeness and logical consistency. Pre coded data was entered on Microsoft office excel program for windows, 2010. Data transferred to the statistical package for social science version 15 (SPSS- V 15) for quantitative data analysis.

Socio-demographic data was analyzed in accordance with the social scoring system suggested by Park and Park 1979. This system is based on the assumption that the level of parents' education and occupation can determine the social standard of the family. Achievable levels of education and type of occupation were appointed certain numerical values and the sum of parents' scores was used to calculate an overall social score. The social standard is based on the classification of the overall score into three levels: [Park and Park, 1979]

1 - Low level if the overall score $<8$

2- Intermediate level if the overall score ranged from 8 to 18

3- High level if the overall score ranged from 19 to 28

Nutrition status was assessed for each participant according to his/her anthropometric measures (weight and height). Body Mass Index = (weight in $\mathrm{Kg} /$ height in $\mathrm{M}^{2}$ ) was calculated according to $\mathrm{WHO}$ cut-off, which are classified into the following classes: [World Health Organization, 2013]

1- Underweight: $\leq 18.5$.

2- Normal: 18.5-24.9.

3- Overweight: 25.0-29.9.

4- Obese: $\geq 30.0$ 


\section{Eman H.ElHabashi, et al}

Obesity is frequently subdivided into categories:

* Class I: BMI of 30 to $<35$

* Class II: BMI of 35 to $<40$

* Class III: BMI of 40 or higher. Class 3 obesity is sometimes categorized as "morbid" or "severe" obesity.

According to WHO recommendations that adults aged 18-64 years should practice at least 150 minutes of moderate-intensity physical activity throughout the week [World Health Organization, 2010]. Consequently physical activity level (PAL) was classified into three categories; low (if participant almost never practice exercise or practicing less than 150 minutes per week), moderate (practice exercise which is equivalent to 150 minutes per week) or high (practice exercise more than150 minutes per week).

Regarding a sedentary lifestyle, it is a way of life with no or little physical activity. An individual adopting a sedentary lifestyle behavior is usually engaged in an activity like socializing, watching television, reading, using a mobile phone/computer or playing video games for much of the day [Owen et al., 2020].

Simple frequency distribution tables were used to describe the studied sample. Quantitative data was presented using mean and standard deviation. Qualitative data was presented cross tabulation presenting the number and percentage for the studied sample. One-Way ANOVA test with post hoc multiple comparisons was used for quantitative data. In categorical data, the Chi-squared test was used for comparison between groups. Significant factors predicting of obesity on uni-variante analysis were entered into multivariate logistic regression analysis to find out the independent predictors of obesity. Odds ratio and $95 \%$ confidence interval was calculated. Differences were considered significant at $P$ value $\leq 0.05$.

\section{Ethical Consideration:}

The study was revised and approved by Ethical committees at public health \& community medicine department at Kasr-Al-Aini Hospital with code (S-9-2018). Informed consent was obtained from all participants before recruitment in the study after explaining the objectives of the work. Confidentiality was guaranteed on handling the data base and questionnaire forms according to revised Helsinki deceleration of biomedical ethics [World Medical Association 2001].

\section{Results}

\section{Baseline population characteristics}

A total of 350 medical students, $112(32 \%)$ males and $238(68 \%)$ females, participated in the study. Their age ranged from 20 to 25 years with mean and standard deviation of $21.33 \pm 0.7$ years. General socio-demographic characteristics of students under study are demonstrated in Table (1).

As regarding lifestyle habits of studied students showed in Table (2), about one third practiced low level of exercise (less than 150 minutes per week) while slightly above half of the participants were adopting a Sedentary lifestyle behavior . 
Egypt. J. of Nutrition and Health Vol. 15 No. 2 July (2020)

\section{Assessment of Body Mass Index and Life style habits:}

Body mass index (BMI) as a nutrition status indicator showed a range from 17.10 to 39.7 $\mathrm{kg} / \mathrm{m}^{2}$ with mean and standard deviation of $24.3 \mathrm{~kg} / \mathrm{m}^{2} \pm 3.9$. It was found that 31 medical students had BMI more than $30 \mathrm{~kg} / \mathrm{m}^{2}$ and were classified as obese, demonstrated in Table (3).

Table (1):

Socio-demographic data of the studied sample

\begin{tabular}{|c|c|c|c|c|c|}
\hline \multirow{2}{*}{\multicolumn{2}{|c|}{ Variables }} & \multicolumn{2}{|c|}{ Frequency } & \multicolumn{2}{|c|}{ Total } \\
\hline & & No. & $\%$ & No. & $\%$ \\
\hline \multirow{2}{*}{ 1-Sex } & Male & 112 & 32 & \multirow[b]{2}{*}{350} & \multirow[b]{2}{*}{100} \\
\hline & Female & 238 & 68 & & \\
\hline \multirow{2}{*}{ 2-Nationality } & Egyptian & 331 & 94.6 & \multirow[b]{2}{*}{350} & \multirow[b]{2}{*}{100} \\
\hline & Non-Egyptian & 19 & 5.4 & & \\
\hline \multirow{2}{*}{ 3- Residence } & Rural & 44 & 12.6 & \multirow[b]{2}{*}{350} & \multirow[b]{2}{*}{100} \\
\hline & Urban & 306 & 87.4 & & \\
\hline \multirow{3}{*}{ 4-Socio-demographic level } & Low & 8 & 2.3 & \multirow{3}{*}{350} & \multirow{3}{*}{100} \\
\hline & Middle & 47 & 13.4 & & \\
\hline & High & 295 & 84.3 & & \\
\hline \multirow{3}{*}{ 5-Accomodation } & With parents & 278 & 79.4 & \multirow{3}{*}{350} & \multirow{3}{*}{100} \\
\hline & University hostels & 36 & 10.3 & & \\
\hline & Private & 36 & 10.3 & & \\
\hline
\end{tabular}

Table (2):

Percent distribution of the studied sample by level of exercise and sedentary life behavior

\begin{tabular}{|c|c|c|c|c|c|}
\hline \multirow{2}{*}{\multicolumn{2}{|c|}{ Variables }} & \multicolumn{2}{|c|}{ Frequency } & \multicolumn{2}{|c|}{ Total } \\
\hline & & No. & $\%$ & No. & $\%$ \\
\hline \multirow{3}{*}{ 1-Practicing exercise } & Low & 109 & 31.1 & \multirow{3}{*}{350} & \multirow{3}{*}{100} \\
\hline & Moderate & 145 & 41.4 & & \\
\hline & High & 96 & 27.4 & & \\
\hline \multirow{2}{*}{ 2- Sedentary lifestyle behavior } & More than 2 hours/ day & 182 & 52 & \multirow[b]{2}{*}{350} & \multirow[b]{2}{*}{100} \\
\hline & Less than 2 hours/ day & 168 & 48 & & \\
\hline
\end{tabular}

Table (3):

Percent distribution of the studied sample by BMI categories

\begin{tabular}{l|c|c}
\hline \multirow{2}{*}{ BMI categories } & No. & $\%$ \\
\cline { 2 - 3 } Underweight & 14 & 4 \\
\hline Normal & 203 & 58 \\
\hline Overweight & 102 & \\
\hline Obese: & & 8.8 \\
Class I & 31 & 0 \\
Class II & 0 & 0 \\
Class III & 0 & 100 \\
\hline Total & 350 & \\
\hline
\end{tabular}




\section{Eman H.ElHabashi, et al}

\section{Food frequency questionnaire:}

Exploring frequency of consumption of some selected food items showed that eating habits related to high risk food items are prevalent among studied youth group such as the daily consumption of poultry with skin $(37.4 \%)$, fats $(33 \%)$, cola $(30 \%)$ and sweets $(47 \%)$. The results show that about one third of studied students have excess sugar intake solely from carbonated soft drinks with daily cola consumption is recorded by $30.3 \%$ of studied group (Table 4 ). On the other hand, there was a low consumption of healthy foods like fruits which were consumed daily by only one third of studied students $(37.7 \%)$ and vegetables which were consumed daily only by half of the participants $(50.3 \%)$ (Table 4).

Table (4):

Percent Distribution of the Studied Sample by their Frequency of Consumption of Some Selected Foods Items.

\begin{tabular}{|c|c|c|c|c|c|c|c|c|}
\hline \multirow{2}{*}{ Food items } & \multicolumn{2}{|c|}{ Almost never } & \multicolumn{2}{|c|}{ Weekly } & \multicolumn{2}{|c|}{ Daily } & \multicolumn{2}{|c|}{ Total } \\
\hline & $\mathrm{N}$ & $\%$ & $\mathrm{~N}$ & $\%$ & $\mathrm{~N}$ & $\%$ & $\mathrm{~N}$ & $\%$ \\
\hline 1-Cereal grains & 6 & 1.7 & 297 & 84.9 & 47 & 13.4 & 350 & 100 \\
\hline 2-Beans & 59 & 16.9 & 73 & 20.9 & 218 & 62.3 & 350 & 100 \\
\hline 3-Red meat & 46 & 13.1 & 53 & 15.1 & 251 & 71.7 & 350 & 100 \\
\hline 4-Fatty meat & 246 & 70.3 & 15 & 4.3 & 89 & 25.4 & 350 & 100 \\
\hline 5-Poultry without skin & 56 & 16.0 & 65 & 18.6 & 229 & 65.4 & 350 & 100 \\
\hline 6-Poultry with skin & 192 & 54.9 & 27 & 7.7 & 131 & 37.4 & 350 & 100 \\
\hline 7-Grilled fish & 132 & 37.7 & 20 & 5.7 & 198 & 56.6 & 350 & 100 \\
\hline 8-Fried fish & 162 & 46.3 & 15 & 4.3 & 173 & 49.4 & 350 & 100 \\
\hline 9-Boiled eggs & 83 & 23.7 & 81 & 23.1 & 186 & 53.1 & 350 & 100 \\
\hline 10-Fried eggs & 106 & 30.3 & 76 & 21.7 & 168 & 48.0 & 350 & 100 \\
\hline 11-Milk\& low fat cheese & 47 & 13.4 & 189 & 54 & 114 & 32.6 & 350 & 100 \\
\hline 12-Fatty cheese & 86 & 24.6 & 120 & 34.3 & 144 & 41.1 & 350 & 100 \\
\hline 13-Fruits & 22 & 6.3 & 198 & 56.6 & 130 & 37.1 & 350 & 100 \\
\hline 14-vegetables & 37 & 10.6 & 137 & 39.1 & 176 & 50.3 & 350 & 100 \\
\hline 15-Sweets & 100 & 28.6 & 85 & 24.3 & 165 & 47.1 & 350 & 100 \\
\hline 16-Fats & 153 & 43.7 & 81 & 23.1 & 116 & 33.1 & 350 & 100 \\
\hline 17-Cola & 165 & 47.1 & 79 & 22.6 & 106 & 30.3 & 350 & 100 \\
\hline 18-Alcohol & 345 & 98.6 & 2 & 0.6 & 3 & 0.9 & 350 & 100 \\
\hline
\end{tabular}

Predictors of obesity

In univariate analysis, it was noted that level of practicing exercise is a highly significant predictor of obesity among the studied group. The non-significant independent variables were gender, nationality, residence, socioeconomic level and sedentary life style behavior (Table 5). 
Egypt. J. of Nutrition and Health Vol. 15 No. 2 July (2020)

Table (5):

Univariate Analysis of Predictors of Obesity among Students.

\begin{tabular}{|c|c|c|c|c|c|c|c|c|}
\hline & \multicolumn{2}{|c|}{ Obese $n=31$} & \multicolumn{2}{|c|}{ Normal $n=203$} & \multicolumn{2}{|c|}{ Total } & \multirow[t]{2}{*}{ OR $(95 \% \mathrm{Cl})$} & \multirow{2}{*}{$\begin{array}{l}P \\
\text { value }\end{array}$} \\
\hline & No & $(\%)$ & No & $(\%)$ & No & $(\%)$ & & \\
\hline \multicolumn{9}{|l|}{ 1-Gender } \\
\hline a)Male & 13 & $16.7 \%$ & 65 & $83.3 \%$ & 78 & $100 \%$ & $1.53(0.71-3.32)$ & \multirow{2}{*}{0.3} \\
\hline b)Female & 18 & $11.5 \%$ & 138 & $88.5 \%$ & 156 & $100 \%$ & Ref & \\
\hline \multicolumn{9}{|l|}{ 2-Nationality } \\
\hline a)Egyptian & 30 & $13.6 \%$ & 190 & $86.4 \%$ & 220 & $100 \%$ & $1.96(0.25-15.5)$ & \multirow{2}{*}{0.2} \\
\hline b)Non-Egyptian & 1 & $7.7 \%$ & 12 & $92.3 \%$ & 13 & $100 \%$ & Ref & \\
\hline \multicolumn{9}{|l|}{ 3-Residence } \\
\hline a)Urban & 29 & $14.0 \%$ & 178 & $86.0 \%$ & 207 & $100 \%$ & $2.04(0.46-9.06)$ & \multirow{2}{*}{0.5} \\
\hline b)Rural & 2 & $7.4 \%$ & 25 & $92.6 \%$ & 27 & $100 \%$ & Ref & \\
\hline \multicolumn{9}{|c|}{ 4-Socioeconomic level } \\
\hline a)High & 29 & $14.8 \%$ & 167 & $85.2 \%$ & 196 & $100 \%$ & $3.00(0.13-9.81)$ & \multirow{3}{*}{0.4} \\
\hline b)Middle & 2 & $6.3 \%$ & 30 & $93.7 \%$ & 32 & $100 \%$ & $1.12(0.23-9.81)$ & \\
\hline c)Low & 0 & $0.0 \%$ & 6 & $100 \%$ & 6 & $100 \%$ & Ref & \\
\hline \multicolumn{9}{|c|}{ 5-Practicing exercise } \\
\hline a)Low & 12 & $18.5 \%$ & 53 & $81.5 \%$ & 65 & $100 \%$ & $2.07(0.76-5.63)$ & \multirow{3}{*}{$0.02^{*}$} \\
\hline b)Moderate & 13 & $13.3 \%$ & 85 & $86.7 \%$ & 98 & $100 \%$ & $1.36(0.58-3.16)$ & \\
\hline c)High & 6 & $8.5 \%$ & 65 & $91.5 \%$ & 71 & $100 \%$ & Ref & \\
\hline \multicolumn{9}{|c|}{ 6-Sedentary lifestyle behavior } \\
\hline a) $>2$ hours/ day & 21 & $16.3 \%$ & 108 & $83.7 \%$ & 129 & $100 \%$ & $1.85(0.83-4.12)$ & \multirow{2}{*}{0.1} \\
\hline b) $<2$ hours/ day & 10 & $9.5 \%$ & 95 & $90.5 \%$ & 105 & $100 \%$ & Ref & \\
\hline
\end{tabular}

$\mathrm{O}=$ odds ratio; $\mathrm{Cl}=$ confidence interval; Ref = reference group.

* Significant association $(P \leq 0.05)$

The independent predictors of obesity as revealed by logistic regression analysis are presented in Table 6. Male students were more than two times more likely to be obese than female students $(O R=2.16)$. 
Eman H.ElHabashi, et al

Table (6):

Logistic Regression Analysis of Independent Predictors of Obesity among Students

\begin{tabular}{|c|c|c|c|c|}
\hline \multicolumn{2}{|c|}{ Predictors } & \multirow{2}{*}{$\begin{array}{c}\text { Coefficient B } \\
0.77\end{array}$} & \multirow{2}{*}{$\frac{P \text { value }}{0.05^{\star}}$} & \multirow{2}{*}{$\frac{\mathrm{OR}(95 \% \mathrm{Cl})}{2.16(0.99-4.70)}$} \\
\hline 1 Gondor & a)Male & & & \\
\hline 1-Genaen & b)Female & - & & Ref \\
\hline \multirow{2}{*}{ 2-Nationality } & a)Egyptian & 1.05 & 0.33 & $2.86(0.34-24.02)$ \\
\hline & b)Non-Egyptian & - & & Ref \\
\hline \multirow{2}{*}{ 3-Residence } & a)Urban & 0.28 & 0.67 & $1.32(0.36-4.88)$ \\
\hline & b)Rural & - & & Ref \\
\hline \multirow{3}{*}{$\begin{array}{l}\text { 4-Socioeconomic } \\
\text { level }\end{array}$} & a)High & 1.17 & 0.39 & $3.21(0.23-10.40)$ \\
\hline & b)Middle & 0.25 & 0.83 & $1.28(0.14-45.14)$ \\
\hline & c)Low & - & & Ref \\
\hline \multirow{5}{*}{$\begin{array}{l}\text { 5-Practicing } \\
\text { exercise }\end{array}$} & a)Low & 0.84 & 0.11 & $2.32(0.83-6.49)$ \\
\hline & b)Moderate & 0.34 & 0.44 & $1.41(0.59-3.38)$ \\
\hline & c)High & - & & Ref \\
\hline & Constant & 0.56 & 0.65 & \\
\hline & \multicolumn{2}{|c|}{ Correctly predicted (\%) } & \multicolumn{2}{|r|}{85.9} \\
\hline
\end{tabular}

$\mathrm{OR}$ = odds ratio; $\mathrm{Cl}=$ confidence interval; $\mathrm{Ref}=$ reference group .

* Significant association $(\mathrm{P} \leq 0.05)$

\section{Frequency of consumption of some food items effect on Students' BMI:}

The study revealed that there was no significant difference regarding dietary consumption of high risk foods among study group and the prevalence of obesity with the P-value more than 0.05 (Table 7). 
Egypt. J. of Nutrition and Health Vol. 15 No. 2 July (2020)

Table (7):

Effect of Frequency of Dietary Consumption of high risk foods on BMI among study group

\begin{tabular}{|c|c|c|c|c|c|c|}
\hline Food items & $\begin{array}{l}\text { Frequency of } \\
\text { Consumption }\end{array}$ & & $\begin{array}{r}=31 \\
\%\end{array}$ & $\begin{array}{l}\text { Normal } \\
n=203 \\
\text { No. } \%\end{array}$ & Total No. \% & $P$ value \\
\hline \multirow{3}{*}{ 1-Fatty meat } & a)Almost never & 22 & $13.6 \%$ & $140 \quad 86.4 \%$ & $162100 \%$ & \multirow{3}{*}{0.45} \\
\hline & b) Weekly & 3 & $23.1 \%$ & $10 \quad 76.9 \%$ & $13 \quad 100 \%$ & \\
\hline & c) Daily & 6 & $10.2 \%$ & $89.8 \%$ & $59 \quad 100 \%$ & \\
\hline \multirow{3}{*}{$\begin{array}{l}\text { 2-Poultry with } \\
\text { skin }\end{array}$} & a)Almost never & 19 & $15.2 \%$ & $106 \quad 84.8 \%$ & $125 \quad 100 \%$ & \multirow{3}{*}{0.46} \\
\hline & b) Weekly & 3 & $16.7 \%$ & $15 \quad 83.3 \%$ & $18 \quad 100 \%$ & \\
\hline & c) Daily & 9 & $9.9 \%$ & $82 \quad 90.1 \%$ & $91 \quad 100 \%$ & \\
\hline \multirow{3}{*}{ 3-Fried fish } & a)Almost never & 13 & $12.5 \%$ & $91 \quad 87.5 \%$ & $104 \quad 100 \%$ & \multirow{3}{*}{0.89} \\
\hline & b) Weekly & 1 & $10.0 \%$ & $90.0 \%$ & $10 \quad 100 \%$ & \\
\hline & c) Daily & 17 & $14.2 \%$ & $10385.8 \%$ & $120 \quad 100 \%$ & \\
\hline \multirow{3}{*}{ 4-Fried eggs } & a)Almost never & 9 & $13.4 \%$ & $86.6 \%$ & $100 \%$ & \multirow{3}{*}{0.61} \\
\hline & b) Weekly & 5 & $9.4 \%$ & $90.6 \%$ & $53 \quad 100 \%$ & \\
\hline & c) Daily & 17 & $14.9 \%$ & $85.1 \%$ & $114 \quad 100 \%$ & \\
\hline \multirow{3}{*}{$\begin{array}{l}\text { 5-Fatty } \\
\text { cheese }\end{array}$} & a)Almost never & 6 & $10.5 \%$ & $89.5 \%$ & $100 \%$ & \multirow{3}{*}{0.32} \\
\hline & b) Weekly & 10 & $10.9 \%$ & $89.1 \%$ & $92 \quad 100 \%$ & \\
\hline & c) Daily & 15 & $17.6 \%$ & $82.4 \%$ & $100 \%$ & \\
\hline \multirow{3}{*}{ 6-Sweets } & a)Almost never & 10 & $16.7 \%$ & $83.3 \%$ & $100 \%$ & \multirow{3}{*}{0.27} \\
\hline & b) Weekly & 5 & $7.7 \%$ & $92.3 \%$ & $65 \quad 100 \%$ & \\
\hline & c) Daily & 16 & $14.7 \%$ & $85.3 \%$ & $109100 \%$ & \\
\hline \multirow{3}{*}{ 7-Fats } & a)Almost never & 10 & $10.1 \%$ & $89.9 \%$ & $100 \%$ & \multirow{3}{*}{0.20} \\
\hline & b) Weekly & 6 & $10.9 \%$ & $89.1 \%$ & $100 \%$ & \\
\hline & c) Daily & 15 & $18.8 \%$ & $81.3 \%$ & $100 \%$ & \\
\hline \multirow{3}{*}{ 8-Cola } & a)Almost never & 10 & $9.3 \%$ & $90.7 \%$ & $108 \quad 100 \%$ & \multirow{3}{*}{0.23} \\
\hline & b) Weekly & 8 & $15.1 \%$ & $84.9 \%$ & $100 \%$ & \\
\hline & c) Daily & 13 & $17.8 \%$ & $82.2 \%$ & $100 \%$ & \\
\hline
\end{tabular}

* Significant association $(\mathrm{P} \leq 0.05)$

However the study revealed a highly significant difference regarding dietary consumption of some healthy foods among study group and the prevalence of obesity, which was significantly lower among students eating Cereal grains, poultry without skin and boiled eggs with the $P$ value $\leq 0.05$ (Table 8). 
Eman H.ElHabashi, et al

Table (8):

Effect of Frequency of Dietary Consumption of healthy food on BMI among the study group

\begin{tabular}{|c|c|c|c|c|c|c|c|c|}
\hline \multirow[t]{2}{*}{ Food items } & \multirow{2}{*}{$\begin{array}{l}\text { Frequency of } \\
\text { Consumption }\end{array}$} & \multicolumn{2}{|c|}{$\begin{array}{l}\text { Obese } \\
n=31\end{array}$} & \multicolumn{2}{|c|}{$\begin{array}{l}\text { Normal } \\
n=203\end{array}$} & \multicolumn{2}{|c|}{ Total } & \multirow[t]{2}{*}{$P$ value } \\
\hline & & No. & $\%$ & No. & $\%$ & & $\%$ & \\
\hline \multirow{3}{*}{ 1-Cereal grains } & a)Almost never & 1 & $50.0 \%$ & & $50.0 \%$ & & $100 \%$ & \multirow{3}{*}{0.05} \\
\hline & b) Weekly & 24 & $11.6 \%$ & 183 & $88.4 \%$ & 207 & $100 \%$ & \\
\hline & c) Daily & 6 & $24.0 \%$ & 19 & $76.0 \%$ & 25 & $100 \%$ & \\
\hline \multirow{3}{*}{ 2-Beans } & a)Almost never & 6 & $15.0 \%$ & 34 & $85.0 \%$ & 40 & $100 \%$ & \multirow{3}{*}{0.47} \\
\hline & b) Weekly & 9 & $17.6 \%$ & 42 & $82.4 \%$ & 51 & $100 \%$ & \\
\hline & c) Daily & & $11.2 \%$ & 127 & $88.8 \%$ & 143 & $100 \%$ & \\
\hline \multirow{3}{*}{ 3-Red meat } & a)Almost never & 3 & $11.1 \%$ & & $88.9 \%$ & 27 & $100 \%$ & \multirow{3}{*}{0.49} \\
\hline & b) Weekly & 3 & $7.9 \%$ & 35 & $92.1 \%$ & 38 & $100 \%$ & \\
\hline & c) Daily & 25 & $14.8 \%$ & 144 & $85.2 \%$ & 169 & $100 \%$ & \\
\hline \multirow{3}{*}{$\begin{array}{l}\text { 4-Poultry } \\
\text { without skin }\end{array}$} & a)Almost never & 1 & $2.5 \%$ & 39 & $97.5 \%$ & 40 & $100 \%$ & \multirow{3}{*}{0.02} \\
\hline & b) Weekly & 4 & $8.5 \%$ & 43 & $91.5 \%$ & 47 & $100 \%$ & \\
\hline & c) Daily & 26 & $17.7 \%$ & 121 & $82.3 \%$ & 147 & $100 \%$ & \\
\hline \multirow{3}{*}{ 5-Grilled fish } & a)Almost never & 14 & $18.2 \%$ & 63 & $81.8 \%$ & 77 & $100 \%$ & \multirow{3}{*}{0.27} \\
\hline & b) Weekly & 1 & $7.7 \%$ & 12 & $92.3 \%$ & 13 & $100 \%$ & \\
\hline & c) Daily & 16 & $11.1 \%$ & 128 & $88.9 \%$ & 144 & $100 \%$ & \\
\hline \multirow{3}{*}{ 6-Boiled eggs } & a)Almost never & 2 & $3.6 \%$ & 54 & $96.4 \%$ & 56 & $100 \%$ & \multirow{3}{*}{0.03} \\
\hline & b) Weekly & 7 & $12.3 \%$ & 50 & $87.7 \%$ & 57 & $100 \%$ & \\
\hline & c) Daily & 22 & $18.2 \%$ & 99 & $81.8 \%$ & 121 & $100 \%$ & \\
\hline \multirow{3}{*}{$\begin{array}{l}\text { 7-Milk\& low-fat } \\
\text { cheese }\end{array}$} & a)Almost never & 2 & $6.7 \%$ & 28 & $93.3 \%$ & 30 & $100 \%$ & \multirow{3}{*}{0.13} \\
\hline & b) Weekly & 14 & $11.1 \%$ & 112 & $88.9 \%$ & 126 & $100 \%$ & \\
\hline & c) Daily & 15 & $19.2 \%$ & 63 & $80.8 \%$ & 78 & $100 \%$ & \\
\hline \multirow{3}{*}{ 8-Fruits } & a)Almost never & 1 & $7.1 \%$ & 13 & $92.9 \%$ & 14 & $100 \%$ & \multirow{3}{*}{0.13} \\
\hline & b) Weekly & 14 & $10.3 \%$ & 122 & $89.7 \%$ & 136 & $100 \%$ & \\
\hline & c) Daily & 16 & $19.0 \%$ & 68 & $81.05 \%$ & 84 & $100 \%$ & \\
\hline \multirow{3}{*}{ 9-Vegetables } & a)Almost never & 5 & $22.7 \%$ & 17 & $77.3 \%$ & 22 & $100 \%$ & \multirow{3}{*}{0.25} \\
\hline & b) Weekly & 9 & $9.8 \%$ & 83 & $90.2 \%$ & 92 & $100 \%$ & \\
\hline & c) Daily & 17 & $14.2 \%$ & 103 & $85.8 \%$ & 120 & $100 \%$ & \\
\hline
\end{tabular}

* Significant association ( $\mathrm{P} \leq 0.05)$

\section{Discussion}

Obesity is believed to be a global epidemic, as it is considered the most rapidly rising form of malnutrition in developed [McTigue et al., 2002] and developing countries [World Health Organization 2000]. Published data demonstrate that obesity is associated with numerous chronic diseases including hypertension, type-2 diabetes, cardiovascular disease (CVD), gallbladder diseases and various malignancies [Manson et al., 2004].

This study showed that among the participants; the obesity prevalence was found to be $8.8 \%$, which is considered lower than the obesity prevalence of the general Egyptian population according to Egypt National STEP-wise Survey for Non-communicable Diseases Risk Factors Report [CAPMAS, 


\section{Egypt. J. of Nutrition and Health Vol. 15 No. 2 July (2020)}

MOHP, and WHO, 2017]. This can be due to the fact that the study subjects' age and medical background make them more concerned about their body weight and healthy lifestyle.

Comparing with medical students in other studies, it was found that this prevalence was close to the results from a study conducted among students in Faculty of Medicine, Northern Border University, Ar'ar, Saudi Arabia which was 8.4\% [Mehmood et al., 2016] and in another study conducted among Health Sciences Students in the Amazonia Region of Peru where the prevalence of obesity was $7.9 \%$ [Rabanales-Sotos et al., 2020]. While the prevalence of obesity among university students attending King Abdulaziz University in Saudi Arabia, was $18.6 \%$ which is higher than this present study results. [Baig et al., 2015] This difference can be explained by the higher percentage of physical inactivity among the King Abdulaziz University study sample (80\%) than the present's study sample which was (31\%).

The moderate level of practicing physical activity in the existent study was in consistence with most of the studies on university students. A study by Askarian et al., 2013, on 400 students showed that less than $10 \%$ of the participants had adequate physical activity level. Another study showed that most students had light physical activity levels, among female colleges [Farrukh 2015]. In contrast, a study conducted in Mansoura University by El-Gilany et al., 2011 upon 1708 students showed that only $11.3 \%$ of participants were physically inactive. This difference from the present study may be due to larger sample size in Mansoura study and different data collection tools used for assessment of physical activity level.

The findings of the present study revealed that a higher percentage of males were obese compared to females (Male students were more than two times more likely to be obese than female students $(O R=2.16)$ ). This result is in accordance with the reported results in some studies conducted in the Middle East; a study in the United Arab Emirates, [Musaiger et al. 2003], another study in Lebanon [Yahia et al. 2008], and one more study in Saudi Arabia [Al-Rethaiaa et al. 2010]. In an additional study that evaluated the prevalence of overweight and obesity among university students from 22 countries in 2014, it was reported that the prevalence of overweight and obesity were found to be significantly higher in males than females in Egypt [Peltzer et al. 2014]. This can be explained that males in their twenties have more muscle mass than females and muscles are heavier than fat [Kirchengast, 2010], therefore, Muscles can make males heavier and increase their BMI. On the other hand, females in their twenties are more aware and concerned about their weight status and body shape than males, as a result of cultural perceptions which encourage females to be slimmer.

Results of the current study showed that there is a significant difference between physical activity level and BMI which was in agreement with that reported by Alkhatani et al, 2015 who stated that association exists between BMI of the students and their physical activity level and proved that the association was significant $(p=0.048)$. On the other hand, the results of this study varies with another study conducted in Nigeria and reported that there is no relationship between physical activity level and BMI of the student [Olariike et al., 2020].

College students face several challenges to adopt healthy eating lifestyle habits, including learning how to buy and cook food, wanting to eat out with their peers, balancing the cost of school and other financial obligations, and navigating a new food environment. [Gaines et al., 2014]

The present study showed the following facts about the participants' dietary habits; among all studied students, the mean intakes of added sugar were high whereas nearly half of the group were consuming sweets daily. And even though it is recommended that the intake of added sugar should be less than 25 grams per day World Health Organization Guidelines, [http://apps.who.int/iris/bitstream] and the fact that a typical 350 milliliter can or bottle of carbonated soft drink contains around 35 grams of 


\section{Eman H.ElHabashi, et al}

sugar, accordingly half of studied students have excess sugar intake solely from carbonated soft drinks (30.3\% consume cola daily). Nevertheless, results revealed no significant difference among participants regarding their dietary consumption of high risk foods and prevalence of obesity.

It is well known that fruits and vegetables play a very important role in reducing overall energy uptake, because of the high contents of its water and fibers [Julie et al., 2008].Unluckily, most of the students consumed less than five servings of fruits and vegetables on an average day which was consistent with the findings for the general Egyptian population [CAPMAS, MOHP, and WHO, 2017], while experts recommended daily consumption of at least $400 \mathrm{~g}$ of fruits and vegetables [WHO 2003]. These findings were in accordance with the results published from two studies; one was conducted on university students in Hong Kong where less than half of the students ate fruits (35.2\%) and vegetables (48.9\%) every day [Lee and Loke, 2005] and the other study was conducted in University of Michigan which showed that among all participating students, mean intakes of fruits, and vegetables were low [Cindy et al., 2019].

As the current study revealed that the prevalence of obesity was significantly lower among medical students eating poultry without skin, boiled egg and cereal grains. This was found to be in agreement with Muñoz-Pareja et al. 2013, who classified the practice of consuming chicken with skin as an obesity related eating behavior and also in accordance with Chang et al. 2018, who stated that eating eggs with its high biological value protein has another benefit of improving satiety that perhaps will help to reduce short-term food intake later in the day. Moreover, Bonnema et al. 2016, revealed that having egg breakfasts showed a reduced postprandial glycemic response and food intake at the following meal when compared to cereal breakfasts. In addition to the confirmation that diet high in whole grain cereals and legumes is associated with lower body mass index, reduced risk of being overweight and can help reduce weight gain [Williams et al., 2008], hence further research is recommended to learn more about forms of cereal grains consumed by the students.

\section{Limitations:}

Several limitations were faced during conducting the current study that should be considered;

1- The participants who volunteered to answer the questionnaire were limited, accordingly the sample was considered as a convenient sample.

2- The participants' food frequency intake was self-reported which may lead to under- or overestimation of intake or desirability.

3- This study presents dietary habits of university students, which may have a better education level and being younger than a population-based sample thus embracing a suitable sample for examining dietary habits, as the variability of health status and education is minimal.

\section{Conclusions}

The prevalence of obesity was $9 \%$ among the studied group of medical students, they were found to practice unhealthy dietary habits of daily consumption of sweets, carbonated drinks and fats. Practicing low level of Physical exercise was a significant predictor of Obesity among the participants.

\section{Recommendations:}

According to the present findings of this study, it is recommend to:

1- Conduct a Nutrition education program targeting university students, aiming at increasing raw fruits and raw vegetables consumption and not to consume fruits at the end of meals, decreasing sweets, soft drinks and fatty foods. 


\section{Egypt. J. of Nutrition and Health Vol. 15 No. 2 July (2020)}

2- Provide a walking track around the college fence to practice walking or jogging in the students' free time may encourage medical students to overcome the time and access barriers they may face to practice physical exercise.

3- $\quad$ Provide healthy snacks options in the cafeterias and canteens that are selling food items inside the universities and that vending machines contain healthy food and beverage products.

\section{Conflict of interest:}

The authors have no conflict of interest to declare.

\section{Acknowledgements:}

Our special thanks go to all the students who participated in this study.

\section{Funding Sources:}

This research did not receive any specific grant from funding agencies in the public commercial, or not-for-profit sectos.

\section{References}

Agyei-Mensah S and de-Graft Aikins A, (2010).

Epidemiological transition and the double burden of disease in Accra, Ghana. J Urban Health. 87(5):879-897. Doi: 10.1007/s11524-010-9492-y.

Alberti K, George MM, Zimmet P and Shaw J, (2005).

The metabolic syndrome? A new worldwide definition. Lancet. 30; 366(9491):1059-62. Doi: 10.1016/S0140-6736(05)67402-8. PMID: 16182882.

Alkahtani, Shaea \& Elkilany, Ahmed \& Al-Mohannadi, Abdulla \& Alduhishy, Anas. (2015).

Relationship between Self-Reported Dietary Intake and Measured Physical Activity among Male Students in the Preparatory Year in University of Dammam in Saudi Arabia. Current Research in Nutrition and Food Science Journal. 3. 130-139. 10.12944/CRNFSJ.3.2.05.

\section{Al-Rethaiaa AS, Fahmy AE, Al-Shwaiyat NM (2010)}

Obesity and eating habits among college students in Saudi Arabia: a cross sectional study. Nutr J 9: 39. [“http://dx.doi.org/10.1186\%2F1475-2891-9-39" It "pmc_ext" 10.1186/1475-28919-39

Askarian M, Deghani Z, Danaei M and Vakili V., (2013).

Knowledge and practice of medical students on healthy lifestyle: a cross-sectional study in Shiraz. J Health Sei Surveill Sys. 1: 77-82

\section{Azadbakht, L. and Esmaillzadeh, A, (2012).}

Macro and micro-nutrients intake, food groups' consumption and dietary habits among female students in Isfahan University of medical sciences. Iran. Red Crescent Med. J. 14, 204-209. 


\section{Eman H.ElHabashi, et al}

Bonnema A.L., Altschwager D.K., Thomas W., Slavin J.L. (2016)

The effects of the combination of egg and fiber on appetite, glycemic response and food intake in normal weight adults-a randomized, controlled, crossover trial. Int. J. Food Sci. Nutr. 67:723-731. doi: 10.1080/09637486.2016.1196654.

CAPMAS (Central Agency for Public Mobilization and Statistics) (Egypt), Ministry of Health and Population (MOHP) (Egypt), World Health Organization (WHO) (2017).

Egypt National STEP-wise Survey for Non-communicable Diseases Risk Factors Report 2017. Available at: https://www.who.int/ncds/surveillance/steps/egypt/en/ [Assessed at July 2019]

Chang C., Lahti T., Tanaka T., Nickerson M.T. (2018).

Egg proteins: Fractionation, bioactive peptides and allergenicity. J. Sci. Food Agric. 98:55475558. doi: 10.1002/jsfa.9150.

Cindy W. Leung, ScD, MPH; Julia A. Wolfson, MPP; Jacob Lahne, MS;Mikayla R. Barry, MPH; Nicole Kasper and Alicia J. Cohen, (2019).

Associations between Food Security Status and Diet-Related Outcomes among Students at a Large, Public Midwestern University. Journal of the academy of nutrition and dietetics. Vol.119, issue 10, p 1623-1631. :https://doi.org/10.1016/j.jand.2019.06.251

Dietary Guidelines for Americans (2015)

U.S Department of Health and Human Services and U.S. Department of Agriculture 20152020 Dietary Guidelines for Americans. 8th Edition [Available at http://health.gov/dietaryguidelines/2015].

El-Gilany A-H., Badawi K., El-Khawaga G. And Awadalla N., (2011).

Physical activity profile of students in Mansoura University, Egypt Eastern Mediterranean Health Journal. Vol. 17 No. 8.

Farrukh Majeed (2015).

Association of BMI with diet and physical activity of female medical students at the University of Dammam, Kingdom of Saudi Arabia Journal of Taibah University Medical Sciences. 10(2), 188-196

Gaines A, Robb CA, Knol LL, Sickler S., (2014).

Examining the role of financial factors, resources and skills in predicting food security status among college students. Int J Consum Stud. 38:374-384.

Gopalakrishnan S, Ganeshkumar P, Prakash MV, Christopher, Amalraj V., (2012).

Prevalence of overweight/obesity among the medical students, Malaysia. Med $\mathrm{J}$ Malaysia. 67(4):442-4. PMID: 23082463.

Grundy SM, Cleeman JI, Daniels SR, Donato KA, Eckel RH and Franklin BA, (2005).

Diagnosis and management of the metabolic syndrome: an American Heart Association/national heart, lung, and blood institute scientific statement. Circulation. 112(17):2735-2752. Doi: 10.1161/CIRCULATIONAHA.105.169404. 


\section{Egypt. J. of Nutrition and Health Vol. 15 No. 2 July (2020)}

Gupta S, Ray TG and Saha I, (2009).

Overweight, obesity and influence of stress on body weight among undergraduate medical students. Indian J Community Med. 34:255-7.

Julie Obbagy, Barbara Jean Rolls, (2008).

The effect of fruit in different forms on energy intake and satiety at a meal. Appetite. $52(2): 416-22$

Kirchengast, Sylvia. (2010).

Gender Differences in Body Composition from Childhood to Old Age: An Evolutionary Point of View. J Life Sci. 2. 1-10. 10.1080/09751270.2010.11885146.

Lee R.L., Loke A.J. (2005)

Health-promoting behavior and psychosocial well-being of university students in Hong Kong. Public Health Nurs. 22(3):209-220.

Likus W, Milka D, Bajor G, Jachacz-Łopata M, Dorzak B, (2013).

Dietary habits and physical activity in students from the Medical University of Silesia in Poland. Rocz Panstw Zakl Hig. 64(4):317-24. PMID: 24693717.

Manson, J. E., Skerrett, P. J., Greenland, P., and Vanltallie, T. B., (2004).

The escalating pandemics of obesity and sedentary lifestyle. A call to action for clinicians. Archives of Internal Medicine. 164(3), 249-258.

McTigue, K. M., Garrett, J. M., and Popkin, B. M., (2002).

The natural history of the development of obesity in a cohort of young U.S. adults between 1981 and 1998. Annals of Internal Medicine. 136(12), 857-864.

Mehmood, Y., Al-Swailmi, F. K., \& Al-Enazi, S. A. (2016).

Frequency of obesity and comorbidities in medical students. Pakistan journal of medical sciences, 32(6), 1528-1532. https://doi.org/10.12669/pjms.326.10492

Muñoz-Pareja M, Guallar-Castillón P, Mesas AE, López-García E, Rodríguez-Artalejo F (2013)

Obesity-Related Eating Behaviors Are Associated with Higher Food Energy Density and Higher Consumption of Sugary and Alcoholic Beverages: A Cross-Sectional Study. PLoS ONE 8(10): e77137. https://doi.org/10.1371/journal.pone.007713

Musaiger AO, Lloyd OL, Al-Neyadi SM, Bener AB (2003).

Lifestyle factors associated with obesity among male university students in the United Arab Emirates. Nutrition \& Food Science 33: 145-147.

Olariike Kayode, Quadri K. Alabi, (2020).

Food consumption patterns, physical activity and overweight and obesity among undergraduates of a private university in Nigeria. Clinical Nutrition Experimental. Vol. 31, P2834. DOI:Ihttps://doi.org/10.1016/j.yclnex.2020.01.001 


\section{Eman H.ElHabashi, et al}

Owen, Neville; Healy, Genevieve N.; Dempsey, Paddy C.; Salmon, Jo; Timpero, Anna; Clark, Bronwyn K.; et al., (2020).

"Sedentary Behavior and Public Health: Integrating the Evidence and Identifying Potential Solutions". Annual Review of Public Health. 41: 265-287. Doi: 10.1146/annurev-publhealth040119-094201. ISSN 0163-7525. PMID 31913771

Park JE and Park K., (1979):

Text Book of Preventive and social Medicine, Seventh Edition. Page 81. Hessers Barinar Sides, ph. Not publisher, 1268 Napier Town.

Peltzer K, Pengpid S, Samuels TA, Özcan NK, Mantilla C, Rahamefy OH, Wong ML, Gasparishvili A. (2014).

Prevalence of overweight/obesity and its associated factors among university students from 22 countries. Int J Environ Res Public Health. 11(7):7425-41. Doi: 10.3390/ijerph110707425. PMID: 25050651 ; PMCID: PMC4113885.

Rabanales-Sotos J, Evangelina Villanueva-Benites M, Jacinto-Magallanes-Castilla J, et al.(2020) Prevalence of Overweight and Obesity among Health Sciences Students in the Amazonia Region of Peru. Healthcare (Basel, Switzerland). 8(4). DOI: 10.3390/healthcare8040538.

Rao CR, Darshan BB, Das N, Rajan V, Bhogun M and Gupta A, (2012).

Practice of physical activity among future doctors: A cross sectional analysis. Int J Prev Med. 3:365-9.

Sajwani RA, Shoukat S, Raza R, Shiekh MM, Rashid Q, Siddique MS, et al.,(2009).

Knowledge and practice of healthy lifestyle and dietary habits in medical and non-medical students of Karachi, Pakistan. J Pak Med Assoc. 59:650-5.

Senekal, M.; Lasker, G.L.; Van Velden, L.; Laubscher, R. and Temple, N.J., (2016)

Weight-loss strategies of South African female university students and comparison of weight management-related characteristics between dieters and non-dieters. BMC Public Health. 16, 918.

Turhan, E.; Inandi, T.; Col, M.; Bugdayci, R.; Eker, O. and Ilhan, M, (2016).

Smoking cessation and attitudes, belief, observation, and education of medical students, in Turkey. J. Nepal Med. Assoc. 54, 55-62.

Vibhute, N. A., Baad, R., Belgaumi, U., Kadashetti, V., Bommanavar, S., \& Kamate, W. (2018). Dietary habits amongst medical students: An institution-based study. Journal of family medicine and primary care, 7(6), 1464-1466. https://doi.org/10.4103/jfmpc.jfmpc_154_18

WHO EMERO (2019).

Obesity-Health topics. Available at: https://www.emro.who.int/health-topics/obesity [Assessed at February 2019 ]

Williams, Peter \& Grafenauer, Sara \& O'Shea, Jane. (2008).

Cereal grains, legumes, and weight management: A comprehensive review of the scientific evidence. Nutrition reviews. 66. 171-82. 10.1111/j.1753-4887.2008.00022.x. 
Egypt. J. of Nutrition and Health Vol. 15 No. 2 July (2020)

World Health Organization (2000).

Obesity: preventing and managing the global epidemic. Report of a WHO Consultation, WHO Technical Report Series (No. 894). ISBN: $92 \quad 4 \quad 120894 \quad 5$. Available at: https://www.who.int/nutrition/publications/obesity/WHO_TRS_894/en

World Health Organization (2003).

Diet, nutrition and the prevention of chronic diseases Report of the joint WHO/FAO expert consultation. WHO Technical Report Series, No. 916 (TRS 916) [https://www.who.int/dietphysicalactivity/publications/trs916/intro/en/]

World Health Organization (2009) .

Global health risks: mortality and burden of disease attributable to selected major risks. World Health Organization. https://apps.who.int/iris/handle/10665/44203

World Health Organization (2010).

Global recommendations on physical activity for health. Geneva, Switzerland: WHO Press.

World Health Organization (2013).

Global Database on Body Mass Index. Available from: http//apps.who.int.bmi/intex.html

\section{World Health Organization}

Guidelines: sugars intake for adults and children. Available at: http://apps.who.int/iris/bitstream/10665/149782/1/9789241549028_eng.pdf. [Assessed at June 2019 ]

World Medical Association. (2001).

World Medical Association Declaration of Helsinki. Ethical principles for medical research involving human subjects. Bulletin of the World Health Organization, $79(4)$, $373-374$. World Health Organization. https://apps.who.int/iris/handle/10665/268312

Yahia N, Achkar A, Abdallah A, Rizk S. (2008)

Eating habits and obesity among Lebanese university students. Nutr J. Oct 30; 7:32. Doi: 10.1186/1475-2891-7-32. PMID: 18973661; PMCID: PMC2584644 
الأنماط الغذائية ومدى انتثار وزيادة الوزن والسمنة و مؤشراتها بين طلاب الطب جامعة القاهرة

\section{دـ.ايمان معوض الحبشي، د.شيرين عصمت حسين ، د. فيروزالعجيزي د.ايمان فؤاد عبدالحميا}

فسم الصحة العامة،كلية الطب قصر العيني، جامعة القاهرة

الملخص العربي

ترتبط الأمر اض غير المعدية ارتباطا وثيقا بالوزن الزائد والسمنة وقد نراجعت الأمراض المعدية

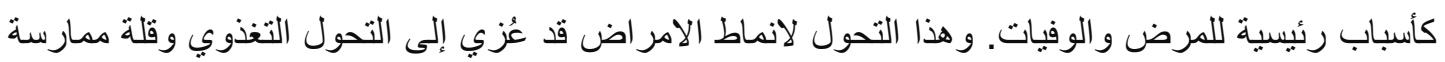

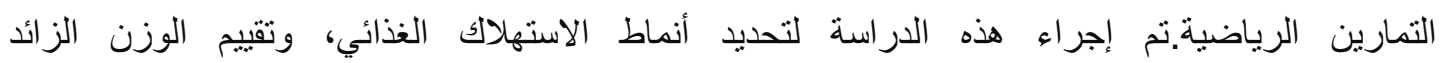

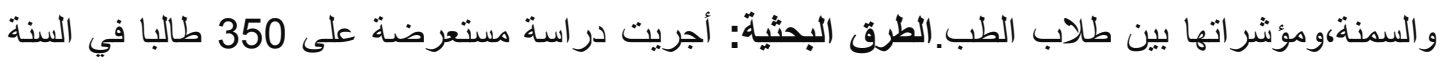

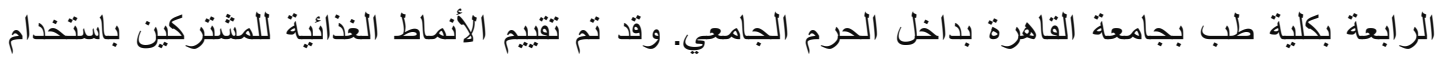

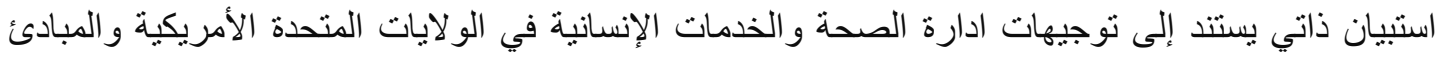

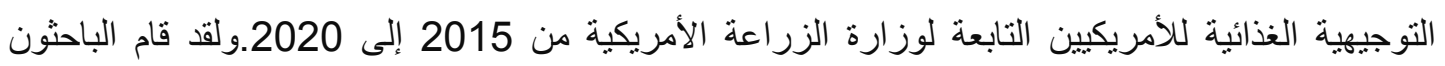

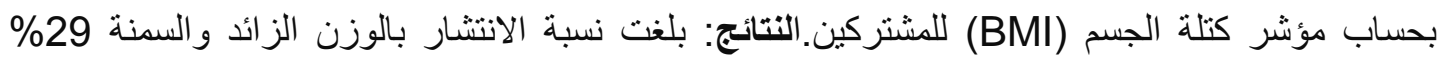

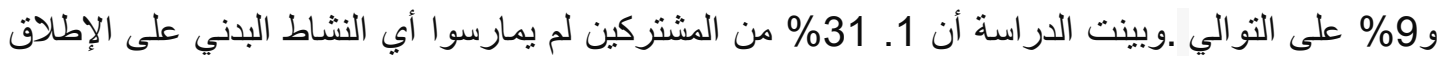

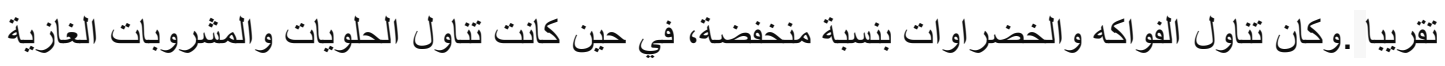

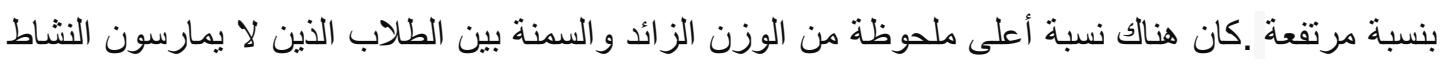

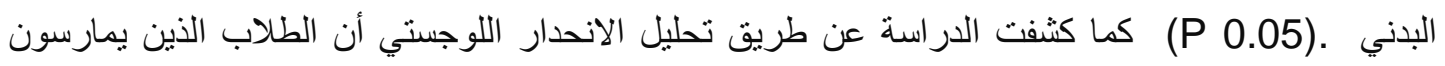

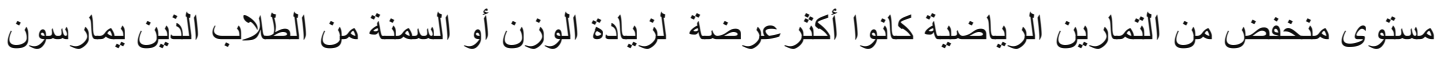

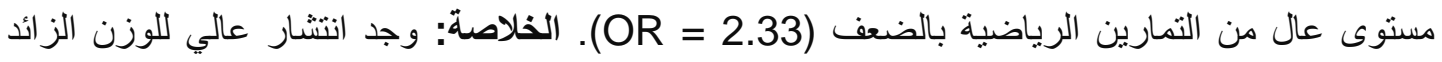

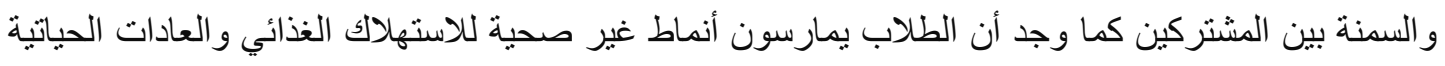
الغير صحية التي كان لها آثار كبيرة على تحديد مستوي مؤشر كتلة الجسم. الكلمات الدالة: الأنماط الغذائية؛ طلاب الطب؛ مؤشر كتلة الجسم ؛ البدانة/السمنة ؛ النشاط البدني؛ التردات

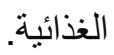


Egypt. J. of Nutrition and Health Vol. 15 No. 2 July (2020)

\section{Appendix 1}

من فضلك لا تكتب اسمك, بيانات هذه الاستمارة سرية و لن تستخدم في غير غرض البحث العلمي

Questionnaire for aassessment of dietary habits among a group of Cairo University Medical Students towards Healthy Diet

استبيان لتقييم العادات الغذائية لدى مجموعة من طلاب الطب بجامعة القاهرة نحو اتباع نظام غذائي صحي
A) Socio-demographic data البيانات الاجتماعية والديموغرافية

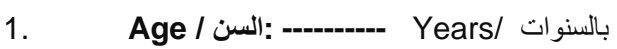

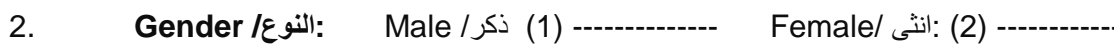

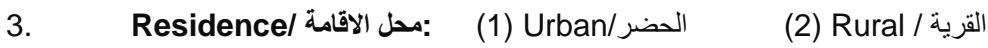

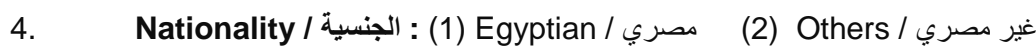
5. Father education/مستوى تعليم الاب:
(1) Illiterate / دي / دي (4) Preparatory

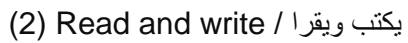
(4) Preparatory / اعدي (1)
(5) ثانوي / دبلوم Secondary/diploma
(3) Primary / ابتدائي
(6) University/Higher
تعليم عالي / education

6. Mother education / مستوى تطليم الام:

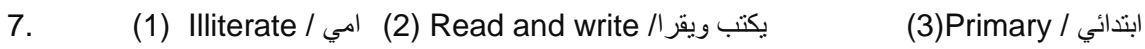

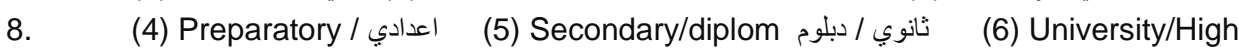
تعليم عالي education

9. مهنة الاب / مه / Father's Job :

(1) No work

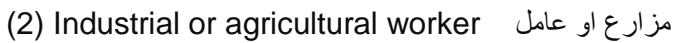

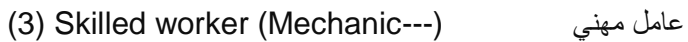

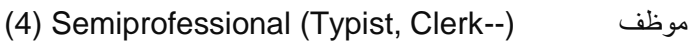

مهنة محترف (5) Professional (Doctor, lawyer, teacher

10. مهنة الام : Mother's Job :

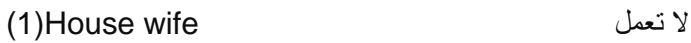

مزارعة او عاملة علة Industrial or agricultural worker

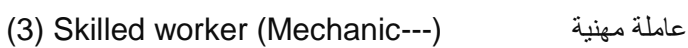

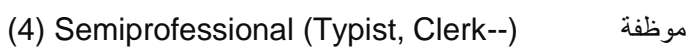

(5) Professional (Doctor, lawyer, teacher مهنة محترفة

11. You are living / مكان المعيثة :

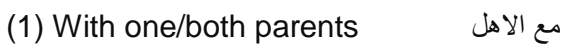

المدينة الجامعية المبل

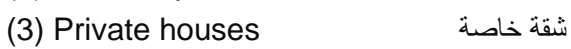


Eman H.ElHabashi, et al

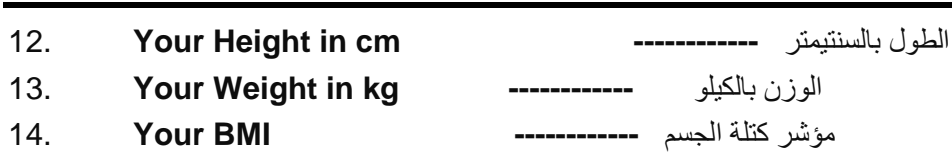

B) Assessing vour physical activity تقييم النشاط البدنى

1. Do you exercise (at least 150 minutes of moderate-intensity physical activity throughout the week including Rapid or slow walking, swimming?

بما في ذللك المشي السريع أو البطيء والسباحة) دقيقة من النشاط المستمرفي الاسبوع 1150- هل تمارس الرياضة (

(1)-Almost Never or Practicing low than 150 mins/week (low) في الاغلب لا

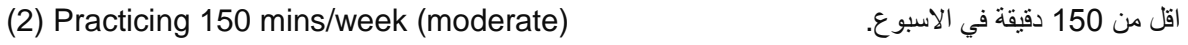

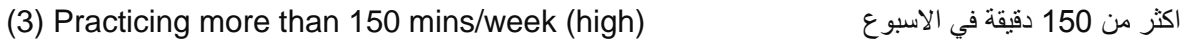

2. Assess your time spent in sedentary activities (ex: watching TV):

2. ثيّم الوقت الذي تقضيه في الأنشطة الخاملة (مثل: مشاهدة التلفزيون)

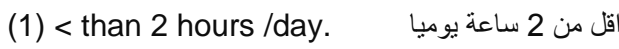

(2) > than 2 hours. /day. اكثر من 2 ساعة يومياعة بوميا

C) How frequently do you eat each of the following foods? All the meals and snacks are considered

كم مرة تأكل كل من الأطعمة التالية؟ يتم اعتبار جميع الوجبات والوجبات الخفيفة 
Egypt. J. of Nutrition and Health Vol. 15 No. 2 July (2020)

\section{Appendix 11}

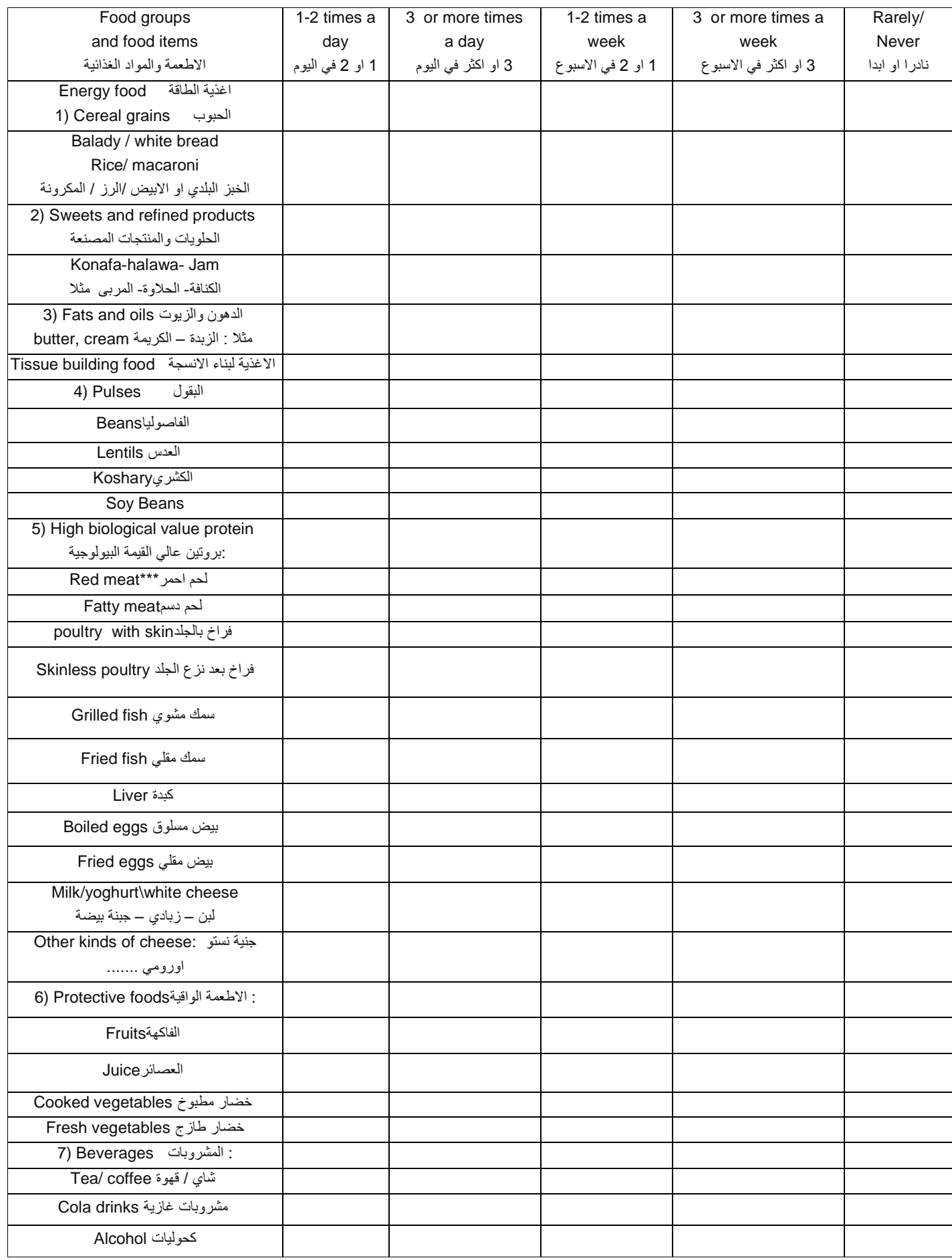

(NNI, 2008) 